\title{
Evaluation \& Management of Accidental Intra-Arterial Injection in the Ante-Cubital Fossa
}

\author{
Jayesh Patel ${ }^{1}$, Pratiksha Shah ${ }^{2 *}$, Fenil Gandhi ${ }^{2}$
}

${ }^{1}$ Head of Department, Department of Vascular Surgery, Shree Krishna Hospital, Gujarat, India; ${ }^{2}$ Intern, Department of Vascular Surgery, Shree Krishna Hospital, Gujarat, India

\begin{abstract}
Introduction: Intra-arterial drug injection is a rare, but a potentially serious medical emergency. It is most commonly seen as an iatrogenic complication when administering an intravenous medication. Accidental Intra-arterial injection was defined as an intravenous injection administered in the upper limb for any illness, which was followed by sudden severe pain in the limb followed by bluish discoloration of any part of the affected limb.
\end{abstract}

Aim: The aim of the study is to identify the risk factors early on for limb amputation following intra-arterial injection. Also, to assess the efficacy of the various modalities of the treatments administered, and establish a standardized treatment plan for intra-arterial injection to achieve limb salvaging.

Materials and methods: A total of twelve cases of accidental intra-arterial injection were studied for the efficacy of early evaluation and management of each. The patients were studied based on Rutherford Classification, clinical history, and Doppler findings.

Results: Ten out of the twelve patients presented early and limb salvation was achieved. Conservative treatment and upper limb Fasciotomy proved to aid with the limb salvation. However, two out of the twelve patients presented after 12 hours with complains of blackening of the digits. In these patients, limb salvation was not achieved and Ray's amputation was performed. All the patients recovered well, with proper functioning of the upper limb.

Conclusion: Early evaluation and management of a case of accidental intra-arterial injection is of utmost importance due to its serious complications. Lastly, all medical professionals must be regularly trained in order to prevent such mishaps from happening.

Keywords: Intra-arterial injection (IA); Diclofenac sodium; Sympathetic ganglion block; Fasciotomy; Ray's amputation

\section{INTRODUCTION}

Accidental intra-arterial injection, whether being self-administered or iatrogenic, is a medical emergency. The normal vascular anatomy, aberrant vasculature, difficult emergency situations and human error, all contribute to the iatrogenic intra-arterial injections in an attempt of getting an intravenous access. Van der Post first reported the condition in 1942 [1]. It is estimated that accidental intra-arterial injection is revealed in 1:3500-1:56000 patients visiting the emergency department [2].

Barbiturates, thiopental sodium, narcotics, and tranquilizers are common drugs that have caused medical catastrophes affecting the upper limb [3]. Diclofenac sodium is also a common over the counter drug being used for analgesia. It is a non-steroidal antiinflammartory drug (NSAIDs) that is commonly used to treat mild to moderate pain, hyperpyrexia, and inflammation. It is most commonly administered through oral, intramuscular, intravenous, transdermal and rectal routes. It can lead to acute ischemia of the affected limb if administered intra-arterially because of its vasospastic action on the arterial wall. Common sites for error are the ante-cubital fossa, groin, and forearm due to the proximity of arteries and the veins at these sites [4].

The immediate reporting of the symptoms and accurate diagnosis are of central importance, as therapeutic strategies range from conservative methods to amputation of the affected limb. The medical sequel that has been most commonly seen is paraesthesia,

${ }^{*}$ Correspondence to: Pratiksha Shah, Department of Vascular Surgery, Pramukhswami Medical College, Shree Krishna Hospital, Karamsad, Gujarat, India, Tel: 6476061140; E-mail: pratiksha_99@hotmail.com

Received: December 02, 2019; Accepted: March 04, 2020; Published: March 14, 2020

Citation: Patel J, Shah P, Gandhi F (2020) Evaluation \& Management of Accidental Intra-Arterial Injection in the Ante- Cubital Fossa. J Vasc Med Surg 8:387. doi: 10.35248/2329-6925.20.8.387.

Copyright: (C) 2020 Patel J, et al. This is an open-access article distributed under the terms of the Creative Commons Attribution License, which permits unrestricted use, distribution, and reproduction in any medium, provided the original author and source are credited. 
severe pain, motor dysfunction, compartment syndrome, gangrene, and limb loss [5]. Acute and/or chronic manifestations can be seen due to accidental IA injection. Several patients complained of immediate discomfort within seconds to a few minutes. The pain may range from local irritation to intense pain, presenting distal to the site of injection. Soon thereafter, many patients also complained of tingling sensations, burning sensations and paraesthesia. Altered motor functions such as involuntary muscle contractures and muscle weaknesses, and cutaneous manifestations such as flushing and mottling have been also commonly reported.

In addition, it has been proposed that there are patients that are at a higher risk of iatrogenic IA injection. Some examples including morbidly obese, dark pigmented patients, thoracic outlet syndrome, patients with indwelling arterial catheters for blood pressure measurement, and pre-existing vascular anomalies of the forearm [5].

A symptomatic classification was established by Rutherford in 1986, revised in 1987 [6]. Rutherford classified peripheral arterial disease in two parts, acute and chronic limb ischemia. The classification associated patient clinical symptoms with objective findings, including Doppler studies, arterial brachial index, and pulse volume recordings. It also emphasized that each presentation requires different treatment algorithms (Table 1).

The above classification was used to diagnose and treat a patient presenting with acute limb ischemia. It has helped the medical professionals to identify high-risk patients and treat accordingly.

The objective of the study is to identify the risk factors early on for limb amputation following intra-arterial injection. Also, to assess the efficacy of the various modalities of the treatments administered, and establish a standardized treatment plan for intraarterial injection to achieve limb salvaging. Since, intra-arterial injections are not a common incidence, it is difficult to follow and establish a standard plan of treatment to prevent an amputation and/or permanent disability.

\section{MATERIALS AND METHODS}

\section{A. Study design}

A case control study was conducted in the Vascular Surgery department of Shree Krishna Hospital from Jan $17^{\text {th }} 2017$ to Dec $30^{\text {th }}$ 2018. A total of twelve patients with iatrogenic intra-arterial injection were studied. Accidental Intra- arterial injection was defined as an intravenous injection administered in the upper limb for any illness, which was followed by sudden severe pain in the limb followed by bluish discoloration of any part of the limb. A thorough clinical history of all the patients was taken, enquiring about the various clinical features they may have experienced; for example pain, weakness, numbness, swelling surrounding the area, blackening of the affected region. Furthermore, the patients were examined for paraesthesia, pallor, and edema, local temperature of the affected region, muscle contractures, and signs of gangrene. Also, the previous records were checked to determine the drug that had been accidentally administered intra-arterially. Simultaneously, all patients had been classified according to the Rutherford Classification, in order to have a better understanding of the severity of the injury. The vitals were constantly monitored from the time of presentation. Following clinical examination, all patients underwent Doppler study to determine the extent of the injury. According to the presenting clinical features, results from the Doppler study, Rutherford classification, the treatment for each patient was determined upon. Moreover, all the patients underwent a thorough clinical examination and Doppler studies post- operatively.

\section{Inclusion criteria:}

1. Patients presenting with signs and symptoms falling under the Rutherford Classification of Acute Limb Ischemia.

2. Patients having a recent history of intravenous drug administration, possibly indicating accidental intra-arterial injection.

3. Patients having positive Doppler findings indicating acute limb ischemia.

\section{Exclusion criteria:}

1. Patients presenting with sensory and motor function loss but no recent history of intravenous drug administration.

2. Patients showing no positive findings on Doppler examination.

\section{B. Ethics}

A verbal consent was taken from each patient to use his/her details for the study. The personal information of all the patients was kept confidential and in no manner manipulated. No harm was done to the patients. The patients' details were solely used for this study only and no other research studies.

\section{RESULTS}

Among the twelve patients, eleven were males and one was a female. The age of the patients ranged from 19-55 years. Ten out of the twelve patients had presented with complains of pain in the right forearm and hand, numbness and tingling sensations, inability to move finger and wrist joint, and swelling of the arm. In addition, upper limb ischemia with blackening of $2^{\text {nd }}$ and $3^{\text {rd }}$ digits and hypothermia of the arm was also present. The patients presented to Trauma and Emergency Care (TEC) within 1 hour of taking an intravenous line where Diclofenac sodium was administered. Upon general examination, the vitals of all the patients were

Table 1: Rutherford classification for acute limb ischemia.

\begin{tabular}{|c|c|c|c|c|c|}
\hline \multirow[b]{2}{*}{ Category } & \multicolumn{3}{|c|}{ Findings } & \multicolumn{2}{|c|}{ Doppler signal } \\
\hline & Description/ Prognosis & Sensory loss & Muscle weakness & Arterial & Venous \\
\hline I. Viable & Not immediately threatened & None & None & Audible & Audible \\
\hline \multicolumn{6}{|l|}{ II. Threatened } \\
\hline a) Marginally & Salvageable if promptly treated & Minimal (toes) or none & None & Inaudible & Audible \\
\hline b) Immediately & $\begin{array}{l}\text { Salvageable with immediate } \\
\text { revascularization }\end{array}$ & $\begin{array}{c}\text { More than toes, associated } \\
\text { with rest pain }\end{array}$ & Mild, Moderate & Inaudible & Audible \\
\hline III. Irreversible & $\begin{array}{l}\text { Major tissue loss or permanent } \\
\text { nerve damage inevitable }\end{array}$ & Profound, anesthetic & Profound, paralysis & Inaudible & Inaudible \\
\hline
\end{tabular}


within normal limits. The local examination of the arm showed that Brachial, Radial and Ulnar arteries were not palpable on the affected side; Axillary artery was palpable. Palpation of all the arteries in the opposite upper limb was plausible. The patients were classified as Category IIb (Immediately, Threatened), according to the Rutherford Classification.

The following treatment was employed immediately in the patients:

1. Injection Heparin 10,000-unit IV stat, followed by 1000 unit/hour infusion. The target APTT being 75-85 seconds. Monitoring was done every 6 hours for 5 days. This was done to prevent thrombosis.

2. Injection Hydrocortisone $200 \mathrm{mg}$ IV TDS for 3 days, followed by $100 \mathrm{mg}$ TDS for 2 days, and $100 \mathrm{mg}$ OD for 2 days. It aided in enhancing tissue repair.

3. Injection Sulfamethoxazole- Trimethoprim $40 \mathrm{ml} /$ hour for 48 hours.

4. Sympathetic ganglion blocks of $0.1 \%$ Ropivacaine $50 \mathrm{ml}$ for 72 hours. Patients reported pain relief with some movement of the digits. Also the local temperature of the digits began to increase.

5. Injection lidocaine (lignocaine) hydrochloride $2 \%$ IV infusion for 5 days. It helped in vasodilation, hence decreasing vasospasm.

6. Tablet Aspirin $75 \mathrm{mg}$ once a day qPM.

7. Intravenous Analgesics.

8. Intravenous Antibiotics.

9. Upper Limb Fasciotomy under general anesthesia.

10. Limb Elevation to favour limb drainage and prevent edema from occurring.

11. Physiotherapy.

12. Doppler ultrasonography was done every 24 hours.

An upper limb arterial Doppler was performed in all the patients. It showed echogenic areas in the distal most part of the affected brachial artery, signs of thrombosis within, and lack of flow in the radial and ulnar artery beyond. The patients were advised to undergo Upper Limb Fasciotomy under general anaesthesia. Upon discharge all vitals of the patients were normal, and limb was successfully salvaged. The patients were advised to keep the limb elevated and physiotherapy was prescribed.

The following drugs were prescribed upon discharge:

1. Oral Antibiotics.

2. Oral Analgesics.

3. Tablet Aspirin $75 \mathrm{mg}$ once a day qPM for 3 months.

4. Doppler USG was performed twice during the follow up to ensure proper functioning of brachial, radial and ulnar arteries.

The patients were asked to come for a follow up examination weekly for two weeks and biweekly afterwards. Upon completion of three months, the wound was completely healed and healthy. In addition, the patients reported of a well-functioning limb.

The remaining two patients had presented with complain of blackening of $1^{\text {st }}, 2^{\text {nd }}$ and $3^{\text {rd }}$ digits. It was gradual in onset and progressive in nature. It was also associated with pain. They also reported a history of a previous injury when an IV line was taken to administer medications. No significant past history was present. Upon general examination, all the vitals of the patients were normal. Local examination showed blackening of the $1^{\text {st }}, 2^{\text {nd }}$, and $3^{\text {rd }}$ digits. The patients were classified as Category III (Irreversible), under the Rutherford Classification.

The following medications were administered immediately as they presented to the Emergency Department:

1. Tablet Aspirin $75 \mathrm{mg}$ once a day in $\mathrm{qPM}$

2. Intravenous Antibiotics

3. Intravenous Analgesics

4. Intravenous Fluids

5. Ray's amputation was performed under sedation and block. Bone nibbled and metacarpophalangeal joints and digits amputated. Sterile dressing was done with limb elevation.

6. Limb Elevation

7. Physiotherapy

Upon discharge the patients were advised a high protein and ketone diet. They were asked to come for a weekly follow up to ensure that the wound was healthy and healing well. No other complains were reported of. The following drugs were prescribed upon discharge:

1. Oral Antibiotics

2. Oral Analgesics

3. Physiotherapy

4. Limb Elevation (Tables 2-4).

Table 2: General details of the patients selected for this study.

\begin{tabular}{|c|c|c|c|c|c|}
\hline Patient & $\begin{array}{l}\text { Age } \\
\text { (Years) }\end{array}$ & Sex & $\begin{array}{l}\mathrm{H} / \mathrm{O} \\
\text { IV line } \\
\text { taken }\end{array}$ & $\begin{array}{l}\text { Drug } \\
\text { Administered }\end{array}$ & $\begin{array}{l}\text { Time from when } \\
\text { the first symptoms } \\
\text { appeared to when they } \\
\text { presented to TEC }\end{array}$ \\
\hline 1) & 19 & Male & Yes & $\begin{array}{l}\text { Diclofenac } \\
\text { Sodium }\end{array}$ & 30 minutes \\
\hline 2) & 35 & Male & Yes & $\begin{array}{l}\text { Diclofenac } \\
\text { Sodium }\end{array}$ & 45 minutes \\
\hline 3) & 35 & Male & Yes & $\begin{array}{l}\text { Diclofenac } \\
\text { Sodium }\end{array}$ & 30 minutes \\
\hline 4) & 36 & Female & Yes & $\begin{array}{l}\text { Diclofenac } \\
\text { Sodium }\end{array}$ & 60 minutes \\
\hline 5) & 38 & Male & Yes & $\begin{array}{l}\text { Diclofenac } \\
\text { Sodium }\end{array}$ & 1.5 hours \\
\hline 6) & 41 & Male & Yes & $\begin{array}{l}\text { Diclofenac } \\
\text { Sodium }\end{array}$ & 60 minutes \\
\hline 7) & 45 & Male & Yes & Unknown & 60 minutes \\
\hline 8) & 50 & Male & Yes & $\begin{array}{l}\text { Diclofenac } \\
\text { Sodium }\end{array}$ & 30 minutes \\
\hline 9) & 51 & Male & Yes & $\begin{array}{l}\text { Diclofenac } \\
\text { Sodium }\end{array}$ & 45 minutes \\
\hline 10) & 55 & Male & Yes & $\begin{array}{l}\text { Diclofenac } \\
\text { Sodium }\end{array}$ & 30 minutes \\
\hline 11) & 36 & Male & Yes & Unknown & After 12 hours \\
\hline 12) & 38 & Male & Yes & Unknown & After 12 hours \\
\hline
\end{tabular}


Table 3: Clinical features and Rutherford classification.

\begin{tabular}{|c|c|c|c|}
\hline Patient & Site of IV Line & Clinical Features & Rutherford Classification \\
\hline \multirow[t]{2}{*}{ 1) } & \multirow{2}{*}{$\begin{array}{l}\text { Right Upper } \\
\text { Limb in the Ante- } \\
\text { cubital Fossa }\end{array}$} & $\begin{array}{l}\text { 1. Pain in the right forearm and hand, numbness and tingling sensations, inability to } \\
\text { move finger and wrist joint }\end{array}$ & \multirow[t]{2}{*}{$\begin{array}{l}\text { Category IIb = Immediately, } \\
\text { Threatened }\end{array}$} \\
\hline & & $\begin{array}{l}\text { 2. Brachial, Radial and Ulnar arteries were not palpable on the right side; Axillary artery } \\
\text { was palpable. Palpation of all arteries on the left side was plausible. }\end{array}$ & \\
\hline \multirow[t]{2}{*}{ 2) } & \multirow{2}{*}{$\begin{array}{l}\text { Right Upper } \\
\text { Limb in the Ante- } \\
\text { cubital Fossa }\end{array}$} & $\begin{array}{l}\text { 1. Pain in the right forearm and hand, numbness and tingling sensations, inability to } \\
\text { move finger and wrist joint, swelling over the forearm }\end{array}$ & \multirow[t]{2}{*}{$\begin{array}{l}\text { Category IIb }=\text { Immediately, } \\
\text { Threatened }\end{array}$} \\
\hline & & $\begin{array}{l}\text { 2. Brachial, Radial and Ulnar arteries were not palpable on the right side; Axillary artery } \\
\text { was palpable. Palpation of all arteries on the left side was plausible. }\end{array}$ & \\
\hline \multirow[t]{2}{*}{ 3) } & \multirow{2}{*}{$\begin{array}{l}\text { Right Upper } \\
\text { Limb in the Ante- } \\
\text { cubital Fossa }\end{array}$} & $\begin{array}{l}\text { 1. Pain in the right forearm and hand, numbness and tingling sensations, inability to } \\
\text { move finger and wrist joint }\end{array}$ & \multirow[t]{2}{*}{$\begin{array}{l}\text { Category IIb }=\text { Immediately, } \\
\text { Threatened }\end{array}$} \\
\hline & & $\begin{array}{l}\text { 2. Brachial, Radial and Ulnar arteries were not palpable on the right side; Axillary artery } \\
\text { was palpable. Palpation of all arteries on the left side was plausible. }\end{array}$ & \\
\hline \multirow[t]{2}{*}{ 4) } & \multirow{2}{*}{$\begin{array}{l}\text { Right Upper } \\
\text { Limb in the Ante- } \\
\text { cubital Fossa }\end{array}$} & $\begin{array}{l}\text { 1. Pain in the right forearm and hand, numbness and tingling sensations, inability to } \\
\text { move finger and wrist joint, hypothermia present }\end{array}$ & \multirow[t]{2}{*}{$\begin{array}{l}\text { Category IIb = Immediately, } \\
\text { Threatened }\end{array}$} \\
\hline & & $\begin{array}{l}\text { 2. Brachial, Radial and Ulnar arteries were not palpable on the right side; Axillary artery } \\
\text { was palpable. Palpation of all arteries on the left side was plausible. }\end{array}$ & \\
\hline \multirow[t]{2}{*}{ 5) } & \multirow{2}{*}{$\begin{array}{l}\text { Right Upper } \\
\text { Limb in the Ante- } \\
\text { cubital Fossa }\end{array}$} & $\begin{array}{l}\text { 1. Pain in the right forearm and hand, numbness and tingling sensations, inability to } \\
\text { move finger and wrist joint, swelling over the forearm }\end{array}$ & \multirow[t]{2}{*}{$\begin{array}{l}\text { Category IIb = Immediately, } \\
\text { Threatened }\end{array}$} \\
\hline & & $\begin{array}{l}\text { 2. Brachial, Radial and Ulnar arteries were not palpable on the right side; Axillary } \\
\text { artery was palpable. Palpation of all arteries on the left side was plausible. }\end{array}$ & \\
\hline \multirow[t]{2}{*}{ 6) } & \multirow{2}{*}{$\begin{array}{l}\text { Left Upper Limb } \\
\text { in the Ante- } \\
\text { cubital Fossa }\end{array}$} & $\begin{array}{l}\text { 1. Pain in the left forearm and hand, numbness and tingling sensations, inability to } \\
\text { move finger and wrist joint }\end{array}$ & \multirow[t]{2}{*}{$\begin{array}{l}\text { Category IIb = Immediately, } \\
\text { Threatened }\end{array}$} \\
\hline & & $\begin{array}{l}\text { 2. Brachial, Radial and Ulnar arteries were not palpable on the left side; Axillary artery } \\
\text { was palpable. Palpation of all arteries on the right side was plausible. }\end{array}$ & \\
\hline \multirow[t]{2}{*}{ 7) } & \multirow{2}{*}{$\begin{array}{l}\text { Right Upper } \\
\text { Limb in the Ante- } \\
\text { cubital Fossa }\end{array}$} & $\begin{array}{l}\text { 1. Pain in the right forearm and hand, numbness and tingling sensations, inability to } \\
\text { move finger and wrist joint, swelling over the forearm }\end{array}$ & \multirow[t]{2}{*}{$\begin{array}{l}\text { Category IIb = Immediately, } \\
\text { Threatened }\end{array}$} \\
\hline & & $\begin{array}{l}\text { 2. Brachial, Radial and Ulnar arteries were not palpable on the right side; Axillary } \\
\text { artery was palpable. Palpation of all arteries on the left side was plausible. }\end{array}$ & \\
\hline \multirow[t]{2}{*}{ 8) } & \multirow{2}{*}{$\begin{array}{l}\text { Left Upper Limb } \\
\text { in the Ante- } \\
\text { cubital Fossa }\end{array}$} & $\begin{array}{l}\text { 1. Pain in the left forearm and hand, numbness and tingling sensations, swelling over } \\
\text { the forearm }\end{array}$ & \multirow[t]{2}{*}{$\begin{array}{l}\text { Category IIb = Immediately, } \\
\text { Threatened }\end{array}$} \\
\hline & & $\begin{array}{l}\text { 2. Brachial, Radial and Ulnar arteries were not palpable on the left side; Axillary } \\
\text { artery was palpable. Palpation of all arteries on the right side was plausible. }\end{array}$ & \\
\hline \multirow[t]{2}{*}{ 9) } & \multirow{2}{*}{$\begin{array}{l}\text { Right Upper } \\
\text { Limb in the Ante- } \\
\text { cubital Fossa }\end{array}$} & $\begin{array}{l}\text { 1. Pain in the right forearm and hand, numbness and tingling sensations, inability to } \\
\text { move finger and wrist joint, swelling over the forearm, hypothermia present }\end{array}$ & \multirow[t]{2}{*}{$\begin{array}{l}\text { Category IIb = Immediately, } \\
\text { Threatened }\end{array}$} \\
\hline & & $\begin{array}{l}\text { 2. Brachial, Radial and Ulnar arteries were not palpable on the right side; Axillary } \\
\text { artery was palpable. Palpation of all arteries on the left side was plausible. }\end{array}$ & \\
\hline \multirow[t]{2}{*}{ 10) } & \multirow{2}{*}{$\begin{array}{l}\text { Left Upper Limb } \\
\text { in the Ante- } \\
\text { cubital Fossa }\end{array}$} & $\begin{array}{l}\text { 1. Pain in the left forearm and hand, numbness and tingling sensations, swelling over } \\
\text { the forearm, hypothermia present }\end{array}$ & \multirow[t]{2}{*}{$\begin{array}{l}\text { Category IIb }=\text { Immediately, } \\
\text { Threatened }\end{array}$} \\
\hline & & $\begin{array}{l}\text { 2. Brachial, Radial and Ulnar arteries were not palpable on the left side; Axillary } \\
\text { artery was palpable. Palpation of all arteries on the right side was plausible. }\end{array}$ & \\
\hline 11) & $\begin{array}{l}\text { Left Upper Limb } \\
\text { in the Ante- } \\
\text { cubital Fossa }\end{array}$ & Blackening of left $1^{\text {st }}, 2^{\text {nd }}$ and $3^{\text {rd }}$ fingers & Category III = Irreversible \\
\hline 12) & $\begin{array}{l}\text { Right Upper } \\
\text { Limb in the Ante- } \\
\text { cubital Fossa }\end{array}$ & Blackening of right $1^{\text {st }}, 2^{\text {nd }}$ and $3^{\text {rd }}$ fingers & Category III = Irreversible \\
\hline
\end{tabular}

\section{DISCUSSION}

Intra-arterial injection is an infrequent event, leading to a serious medical emergency. It may be iatrogenic and/or in relation to drug abuse. The most common site for intra-arterial injection is the ante-cubital fossa where the branches of brachial and ulnar arteries are superficial and can be easily entered. Some of the proposed mechanisms that explain the emergency are vasospasm, intravascular thrombosis, and chemical endarteritis [7]. The following events lead to acute thrombosis of the affected artery, followed by a decrease in blood supply to the digits. This will eventually lead to the development of gangrene of the affected limb. Also, it has been previously proposed that the benzyl alcohol preservative used in the non- aqueous preparation of diclofenac could be the cause of the emergency vasospasm due to endothelial edema and capillary endothelial dysfunction

Conservative treatment comprised of vasodilators, thrombolytic, steroids, nerve blocks, analgesics, and prophylactic antibiotics. Lidocaine Hydrochloride is a local anesthetic agent, which is a sterile, non- pyrogenic solution. It was one of the drugs administered to the patients who presented early and with no signs of gangrene, where it leads to vasodilatation of the artery. Low molecular weight heparin was administered to prevent further 
Table 4: Investigations and treatment.

\begin{tabular}{ll}
\hline Patient & Doppler USG study \\
1) & $\begin{array}{l}\text { Echogenic areas in the distal most part of right brachial } \\
\text { artery, signs of thrombosis within, and lack of flow in } \\
\text { the right radial and ulnar artery beyond. }\end{array}$ \\
\hline 2) & $\begin{array}{l}\text { Echogenic areas in the distal most part of right brachial } \\
\text { artery, signs of thrombosis within, and lack of flow in } \\
\text { the right radial and ulnar artery beyond. }\end{array}$ \\
3) & $\begin{array}{l}\text { Echogenic areas in the distal most part of right brachial } \\
\text { artery, signs of thrombosis within, and lack of flow in } \\
\text { the right radial and ulnar artery beyond. }\end{array}$
\end{tabular}

Treatment

Outcome

4) Echogenic areas in the distal most part of right brachial artery, signs of thrombosis within, and lack of flow in the right radial and ulnar artery beyond.

Right Upper Limb Fasciotomy Healthy wound upon follow up

Limb Elevation Functions of the limb were restored

Right Upper Limb Fasciotomy Healthy wound upon follow up

Right Upper Limb Fasciotomy Healthy wound upon follow up

Limb Elevation Functions of the limb were restored

Physiotherapy Limb was salvaged

Right Upper Limb Fasciotomy Healthy wound upon follow up

Limb Elevation Functions of the limb were restored

Physiotherapy Limb was salvaged

5) Echogenic areas in the distal most part of right brachial artery, signs of thrombosis within, and lack of flow in the right radial and ulnar artery beyond.

6) Echogenic areas in the distal most part of left brachial artery, signs of thrombosis within, and lack of flow in the left radial and ulnar artery beyond.

Right Upper Limb Fasciotomy Healthy wound upon follow up

Limb Elevation Functions of the limb were restored

Physiotherapy Limb was salvaged

Left Upper Limb Fasciotomy Healthy wound upon follow up

Limb Elevation Functions of the limb were restored

Physiotherapy Limb was salvaged

7) Echogenic areas in the distal most part of right brachial artery, signs of thrombosis within, and lack of flow in the right radial and ulnar artery beyond.

8) Echogenic areas in the distal most part of left brachial artery, signs of thrombosis within, and lack of flow in the left radial and ulnar artery beyond.

Right Upper Limb Fasciotomy Healthy wound upon follow up

Limb Elevation

Functions of the limb were restored

Physiotherapy Limb was salvaged

Left Upper Limb Fasciotomy Healthy wound upon follow up

Limb Elevation Functions of the limb were restored

Physiotherapy Limb was salvaged

9) Echogenic areas in the distal most part of right brachial artery, signs of thrombosis within, and lack of flow in the right radial and ulnar artery beyond.

10) Echogenic areas in the distal most part of left brachial artery, signs of thrombosis within, and lack of flow in the left radial and ulnar artery beyond.

11) Amputation Done, Doppler Findings - Not applicable

12) Amputation Done, Doppler Findings - Not applicable

Right Upper Limb Fasciotomy Healthy wound upon follow up

Limb Elevation Functions of the limb were restored

Physiotherapy Limb was salvaged

Left Upper Limb Fasciotomy Healthy wound upon follow up

Limb Elevation Functions of the limb were restored

Physiotherapy Limb was salvaged

Ray's Amputation of left 1st, Amputation stump was healthy upon follow up 2nd and 3rd fingers

\begin{tabular}{ll}
\hline Limb Elevation & 1st, 2nd, and 3rd fingers not salvaged \\
\hline Physiotherapy & Left Upper Limb functioning well otherwise \\
$\begin{array}{l}\text { Ray's amputation of right 1st, } \\
\text { 2nd and 3rd fingers }\end{array}$ & $\begin{array}{l}\text { Amputation stump was healthy upon follow up } \\
\text { Limb Elevation }\end{array}$ \\
\hline Physiotherapy & 1st, 2nd, and 3rd fingers not salvaged \\
\hline
\end{tabular}

thrombosis from occurring. Monitoring of coagulation parameters was also performed to anticipate and prevent serious bleeding complications. Streptokinase and urokinase are other thrombolytic agents that have proven to be effective in reducing vasospasm. Hydrocortisone is a steroid, which prevents the release of substances that lead to inflammation. When administered in patients, it aided in enhancing tissue repair. The utmost important modality, which proved to be of significance, was the sympathetic ganglion block. Patients reported of a decrease in pain and an increase in local temperature. The sympathetic nerve block targets the sympathetic nervous system, which contains a series of nerves that spread out from the spine to the body, helping to control several involuntary bodily functions. Furthermore, rest, physiotherapy, and elevation to the affected limb are of importance as it leads to a decrease in edema and speeds the recovery process.
Treatment for IA injection also comprises of surgical modalities, which are employed in almost all the patients. Patients that presented early, with no clinical features of gangrene, can be easily operated upon to salvage the limb. Fasciotomy was the procedure performed, where the tissue surrounding the area was cut open to relieve pressure. It is a surgery to relieve swelling and pressure from any compartment of the body. This helps to increase blood flow, and to stop/slow down the rate of damage to the local tissue. Some complications that may appear are excessive bleeding, scarring, infection, and chronic pain. Moreover, patients that presented late and with clinical features of gangrene were immediately treated with Ray's amputation of the affected digits. The gangrene was halted at the very minimum severity as possible, hence preserving some function of the affected digits. In a different article, Samantha and Samantha reported cases of accidental intra-arterial injection 
where the patient presented with necrosis of the finger for which amputation was performed [8]. Diclofenac sodium was injected in the radial artery, which was mistaken for a vein. The rate of amputation for accidental intra-arterial drug injection in such cases is $29 \%$ [9]. In addition, it is of utmost importance to follow up with the patients to ensure proper functioning of the limb and to discover any occurrence of further complications.

Complications occurring due to iatrogenic intra-arterial injection have an incidence between 1:3500 to $1: 56000$ as reported by several authors [10]. Some of the reported complications being acute limb ischemia, unbearable pain at the site of injection, numbness, tingling sensations, inability to move the limb, and lastly the onset of gangrene. All the patients that were studied reported of two or more of the above mentioned complications. This study has helped to identify a standardized treatment plan that has worked in salvaging the limb. Although, the treatment plan can always be modified according to the patients' needs and their clinical features.

\section{CONCLUSION}

Clinically, it may not be easy to prevent cases of accidental intraarterial injection from occurring, however incidence can be lowered with supervision and proper training of the medical personnels. It is important that a medically trained physician supervise this task, in order to prevent such catastrophes from happening. Furthermore, it is important to identify the signs early on, and administer appropriate treatment to reduce the possibility of amputation and prevent the patient from having a permanent disability. Lastly, a clinician must not forget to educate and inform the patient of the possible outcome of his/her condition. The patients must be taken care of with the utmost care.

\section{FROM ALL AUTHORS}

- No Conflict of Interest
- No Financial Disclosures

- No Acknowledgements

\section{REFERENCES}

1. Van der Post CWH. A case of mistaken injection of Pentothal sodium into an aberrant ulnar artery. S Afr Med J. 1942;16:182-184.

2. Malik A, Ikramullah, Khan MG, Ali Shah SM, Ilyas M. Accidental Intra Arterial Injection and Limb Ischemia. J Ayub Med Coll Abbottabad. 2017;29(2):230-233

3. Kumar M, Singh J, Sharma P, Khera A, Singh P. Accidental IntraArterial Injection of Diclofenac -Case Report. J Clin Diagn Res. 2015;9(1):16-17.

4. Caroline Lake, Christina L Beecroft. Extravasation Injuries and Accidental Intra-Arterial Injection. Continuing Education in Anaesthesia Critical Care \& Pain. 2010;10(4):109-113.

5. Surjya Sen, Eduardo Nunes Chini, Michael J. Brown. Complications after Unintentional Intra-Arterial Injection of Drugs: Risks, Outcomes, and Management Strategies. Mayo Clinic. 2005;80(6):783-795.

6. Cohen SM. Accidental Intra-Arterial Injection of Drugs. Lancet. 1948;2(6523):361.

7. Ghouri AF, Mading W, Prabaker K. Accidental Intraarterial Drug Injections via Intravascular Catheters Placed on the Dorsum of the Hand. Anesth Analg, 2002;95(2):487-491.

8. Sukhen Samanta, Sujay Samanta. Accidental intra-arterial injection of diclofenac sodium and their consequences: report of two cases. Anaesth pain \& intensive care. 2013;17(1):101-102.

9. Devulapalli C, Han KD, Bello RJ, LaPorte DM, Hepper CT, Katz RD. Inadvertent Intra-Arterial Drug Injections in the Upper Extremity: Systematic Review. J Hand Surg Am. 2015;40(11):2262-2268.e5.

10.Stone HH, Donnelly CC. The Accidental Intraarterial Injection of Thiopental. Anesthesiology. 2006;22:995-1006. 